\title{
ПЕРЕОПИСАНИЕ ОРДОВИКСКИХ ДВУСТВОРЧАТЫХ МОЛЛЮСКОВ ИЗ КОЛЛЕКЦИИ Э. ЭЙХВАЛЬДА
}

Двустворчатые моллюски из средне- и верхнеордовикских отложений северо-западной окраины Восточно-Европейской платформы (территория Эстонской ССР и Ленинградской области), впервые описанные Э. Эйхвальдом (Eichwald, 1840, 1856, 1860; Эйхвальд, 1861), хранятся на кафедре исторической геологии Ленинградского государственного университета (КИГ ЛГУ) под коллекционными номерами 1 и 4 (Баулер, Порецкая, 1959). Это в основном ядра различной сохранности: на некоторых видны мускульные отпечатки, на некоторых - строение замка.

Авторы попытались уточнить родовую принадлежность и стратиграфическое распространение изученных Э. Эйхвальдом форм. Однако несколько экземпляров утеряно, а синтипы иногда отсутствуют или относятся к отличным от оригинала видам и даже родам. Очень затруднительным оказалось уточнение геологического распространения видов. Привязка преобладающего большинства палеонтологических объектов у Э. Эйхвальда ограничивается названием населенного пункта, вблизи которого выходят на поверхность ордовикские отложения, относящиеся к различным стратиграфическим единицам. Кроме того, местонахождения, указанные в ранних работах (Eichwald, 1840, 1856), нередко не совпадают с приведенными в «Палеонтологии Россин» (Эйхвальд, 1861), что в ряде случаев увеличивает неясность стратиграфического распространения. Для выяснения распространения некөторых видов был использован дополнительный материал, собранный сотрудниками геологического отдела Зоологического музея Тартуского государственного университета и палеонтологической лаборатории Ленинградского государственного университета (пал. лаб. ЛГУ), а также Р. Ф. Геккером (1922-1927), Е. М. Люткевичем (1927), Б. П. Асаткиным (1926) из Центрального государственного музея им. Ф. Н. Чернышева (ЦГМ).

Авторы приносят глубокую благодарность профессору А. Рыымусоксу за уточнение стратиграфических привязок палеонтологического материала и приведение их в соответствие с принятой в настоящее время схемой стратиграфии этого региона (Рыымусокс, 1970; Решения ..., 1978).

В статье приведены диагнозы и изображения 11 видов двустворчатых моллюсков из среднего и верхнего ордовика.

Семейство Ctenodontidae Wöhrmann, 1893

Род Tancrediopsis Beushausen, 1895

Tancrediopsis macromya (Eichwald), 1856

Табл. I, фиг. 1

1856 Nucula macromya Eichwald, c. 568

1860 Nucula macromya Eichwald, c. 992, табл. XXXVIII, фиг. 9 
1861 Nucula macromya Eichwald; Әйхвальд, с. 281, табл. XVII, фиг. ? Лектотип (выбранный здесь). КИГ ЛГУ, № 1/864, ядро правой створки, изображенное Э. Эйхвальдом (1860, табл. XXXVIII, фиг. 9), Северная Эстония, Эрра, вируская серия, кукрузеский горизонт, вийвиконнаская свита $\left(\mathrm{C}_{\mathrm{I}} \mathrm{c}-\mathrm{C}_{\mathrm{II}} \mathrm{V}\right)$.

Диагноз. Раковина треугольно-овальная, длиной до 17 мм. Задний конец несколько у́же переднего, немного оттянутый. Раковина умеренно и равномерно выпуклая. Макушки широкие, округленные, прямые, немного сдвинутые вперед. Мускульные отпечатки овальные, крупные, отчетливые, почти равной величины. Выше аддукторов видны отпечатки маленьких педальных мускулов. Зубы шевронообразные, острия шевронов обращены к макушке.

Геологическое распространение. Северная Эстония. Кукрузеский горизонт, вийвиконнаская свита $\left(\mathrm{C}_{\mathrm{I}} \mathrm{c}-\mathrm{C}_{\mathrm{II}} \mathrm{V}\right)-$ Эрра, 3 экз. (лектотип и 1 синтип из коллекции Эйхвальда), Кохтла, 3 экз., Убья, 2 экз., Кява, 2 экз., Кюттейыу, 2 экз.

Замечание. Имеющийся в нашем распоряжении материал не подтверждает данных Э. Әйхвальда о находке $T$. macromya вблизи Кирна (Саунья) (харьюская серия, набалаский горизонт). Сборы Э. Эйхвальда из этого местонахождения не сохранились.

Род Dystactella Hall \& Whitfield, 1872

Dystactella (?) aedilis (Eichwald); 1856

Табл. I, фиг. 2,3

1856 Nucula aedilis Eichwald, c. 568

1860 Nucula aedilis Eichwald, c. 991, табл. XXXVIII, фиг. 10a-c

1861 Nucula aedilis Eichwald; Эйхвальд, с. 281, табл. XVII, фиг. 10a-c

Лектотип (выбранный здесь). КИГ ЛГУ, № 1/863, полное ядро, изображенное Э. Эйхвальдом (1860, табл. XXXVIII, фиг. $10 a-c)$. Эрра, вируская серия, кукрузеский горизонт, вийвиконнаская свита $\left(\mathrm{C}_{\mathrm{I}} \mathrm{c}-\mathrm{C}_{\mathrm{II}} \mathrm{V}\right)$.

Диагноз. Раковина вытянуто-овальная, длиной обычно около 20 мм, максимально до 35 мм, сильно неравносторонняя, передний конец вытянутый, задний короткий, округленный, у́же переднего. Раковины сильно выпуклые (коэффициент выпуклости до 0,45 ), от макушки к задней трети нижнего края проходит очень слабая широкая депрессия, которой соответствует спрямление или слабый синус нижнего края. Макушки довольно широкие, наклоненные к замочному краю, сдвинутые назад. Мускульные отпечатки крупные (особенно передний), овальные, часто со слабой струйчатостью на поверхности. Позади макушек расположена глубокая овальная ямка, где находилась связка. Поверхность ядер несет пологие концентрические морщины.

Замечание. Описанный вид по форме и по большой выпуклости раковин очень близок к девонскому роду Dystactella (McAlester, 1968, p. 27, pl. 5, fig. 1-11). По А. Л. Мак-Алистеру (McAlester, 1969, p. 228, pl. AI, fig. $1 a-b)$, род Dystactella объединен с родом Clinopistha. Однако раковины $D$. ? aedilis существенно отличаются от раковин Clinopistha очертаниями и формой макушек и глубокой связочной ямкой. Авторы присоединяются к мнению Дж. Поёта (Pojeta, 1978, p. 18) о возможности выделения этих двустворок в новый род.

Геолоғическое распространение. Северная Эстония. Кукрузеский горизонт, вийвиконнаская свита $\left(\mathrm{C}_{\mathrm{I}} \mathrm{c}-\mathrm{C}_{\mathrm{II}} \mathrm{V}\right)-$ Эрра, 2 экз. (лектотип), 
Кюттейыу, 33 экз. (из них 3 из колл. пал. лаб. ЛГУ), Кохтла-Ярве, 14 экз., карьер Октябрьский, 5 экз., Ууэмыйза, 5 экз., Кивиыли, 1 экз., Вийвиконна, 2 экз. (из колл. пал. лаб. ЛГУ), Убья, 19 экз., Хумала, 1 экз., Ласнамяги, ул. Пунане, 2 экз.

Ленинградская область. Ухакуский или кукрузеский горизонт $\left(\mathrm{C}_{\mathrm{I}} \mathrm{c}-\mathrm{C}_{\mathrm{II}} \mathrm{V}\right)-$ Веймарн, 28 экз.

Семейство Cyrtodontidae Ulrich, 1894

Род Cyrtodontula Tomlin, 1931

Cyrtodontula ? esthona (Eichwald), 1856

Табл. I, фиг. 4,5

1856 Cypricardia esthona Eichwald, c. 572

1860 Cypricardia esthona Eichwald, c. 1012, табл. XXXIX, фиг. $7 a-8$

1861 Cypricardia esthona Eichwald; Эйхвальд, с. 228, табл. XVIII, фиг. $7 a-8$

Голотип. КИГ ЛГУ, № 1/880, полное ядро, изображенное Э. Эйхвальдом (1860, табл. XXXIX, фиг. $7 a-8)$, окрестности Раквере, раквереский горизонт, воореская свита.

Диагноз. Раковина овальная, длиной около 30 мм, очень неравносторонняя, значительно и равномерно выпуклая (коэффициент выпуклости близок к 0,4). Умбональный гребень широкий, округленный, слабо выраженный. Макушки небольшие, сильно сдвинутые и немного повернутые вперед. Передний мускульный отпечаток небольшой, круглый; задний - более крупный, нечеткий. Хорошо развит длинный и довольно широкий щиток.

Геологическое распространение. Северная Эстония. Раквереский горизонт, воореская свита (EV) - Раквере, 1 экз. (голотип).

Род Plethocardia Ulrich, 1892

Plethocardia obtusa (Eichwald), 1860

Табл. I, фиг. 6,7

1860 Isocardia obtusa Eichwald, c. 1025, табл. XXXIX, фиг. 26a-8

1861 Isocardia obtusa Eichwald; Эйхвальд, с. 292, табл. XVIII, фиг. $26 a-8$

Голотип. КИГ ЛГУ, № 1/893, полное ядро, изображенное Э. Эйхваль-

\section{ТАБЛИЦА I}

Фиг. $I$ - Tancrediopsis macromya (Eich.), лектотип № 1/364, ядро правой створки, Эрра. Фиг. 2, 3 - Dystactella ? aedilis (Eich.), лектотип № 1/863, Эрра, 2 - ядро двустворчатого экземнляра со стороны левой створки, 3 - вид со стороны замочного края. Фиг. 4,5-Cyrtodontula ? esthona (Eich.), голотип № 1/880, Раквере, 4 - ядро двустворчатого экземпляра со стороны левой створки, 5 - вид со стороны замочного края. Фиг. 6, 7 - Plethocardia obtusa (Eich.), голотнп № 1/893, о-в Хийумаa, Кыргессааре, 6 - ядро двустворчатого экземпляра со стороны левой створки, 7 - вид со стороны переднего края. Фиг. 8 - Cypricardia inflata Eichwald, КИГ ЛГУ № 1/345, Таллин, ядро двустворчатого экземпляра со стороны левой створки. Фиг. 9, 10 - Veimarnella globosa (Eich.), лектотип № 1/820, Таллин, 9 вид со стороны замочного края, 10 - ядро двустворчатого экземпляра со стороны правой створки. Фиг. 11 - Modiolopsis plana (Eich.), лектотип № 1/799, ядро левой створки, О-в Осмуссаар или Раквере. Увеличение всюду $\times 1$. 
ТАБЛИЦА I
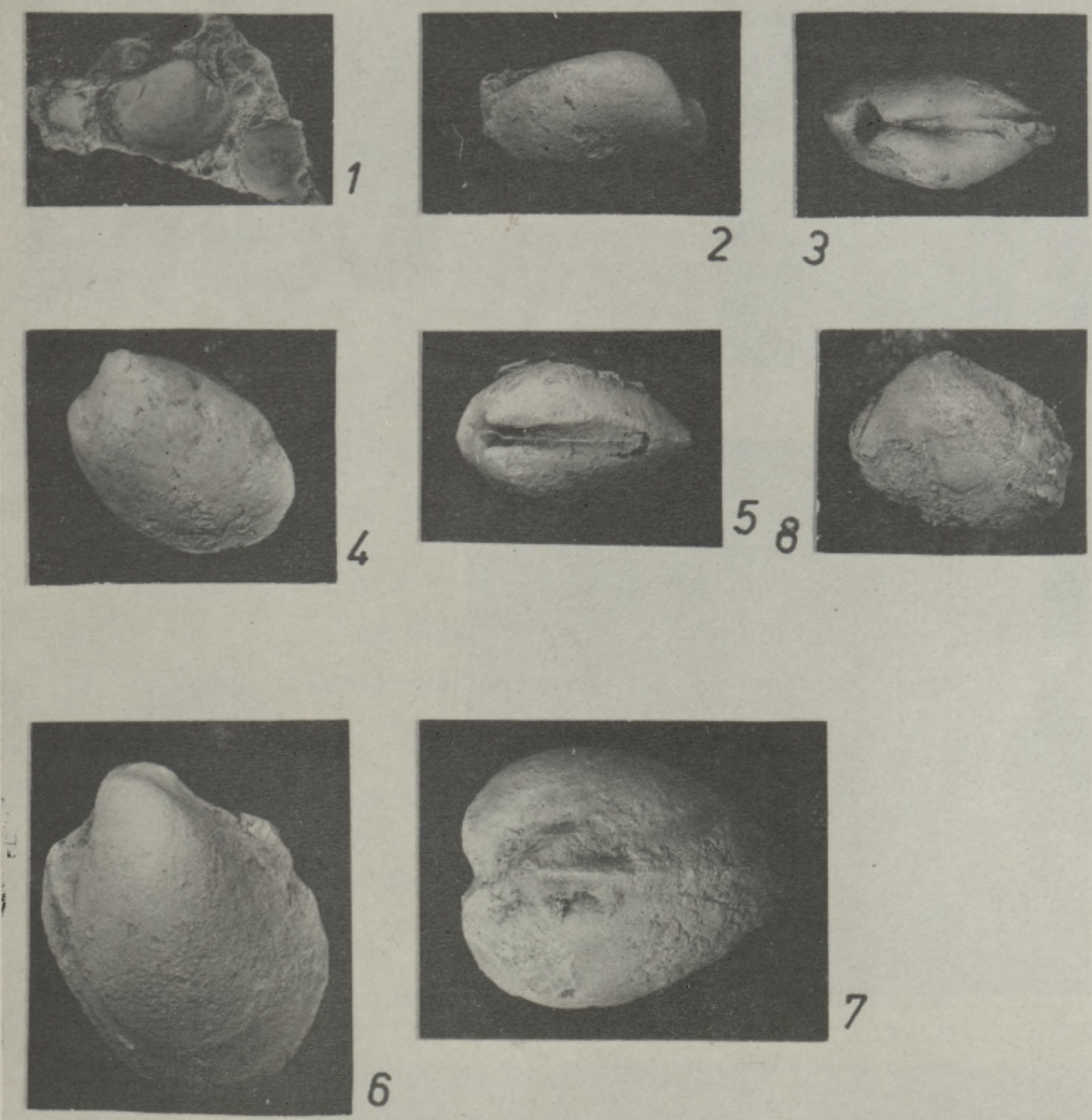

6
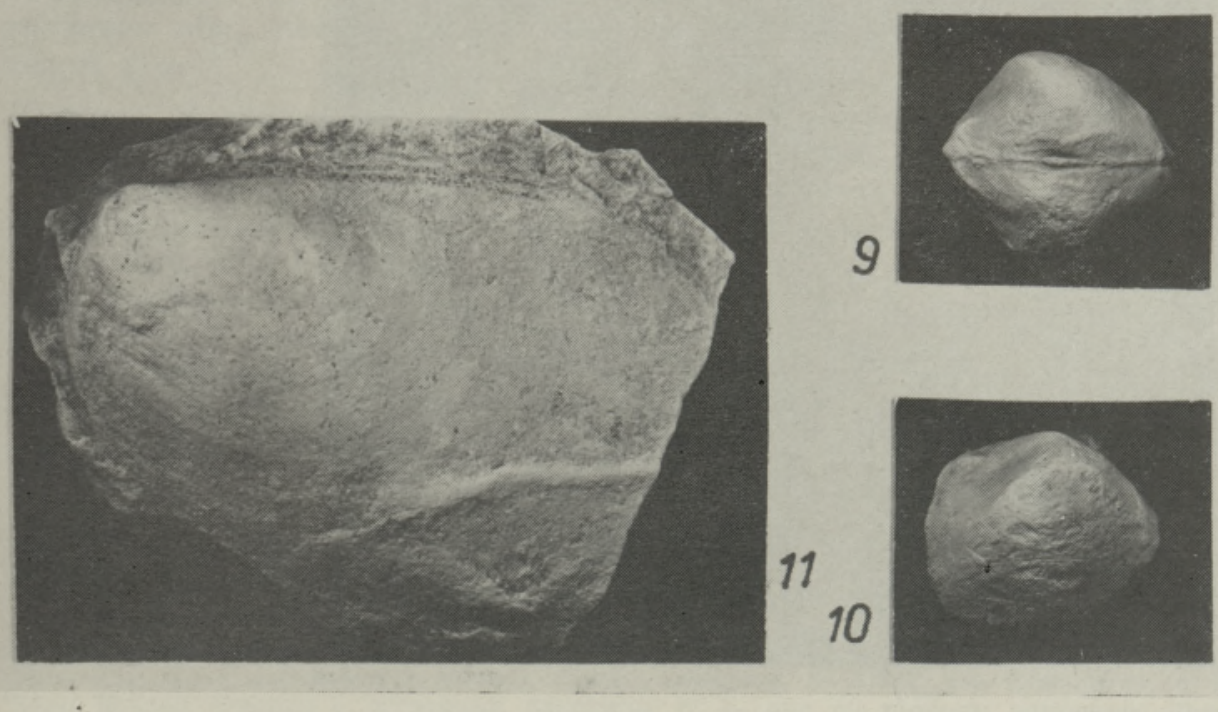
ТАБЛИЦА II
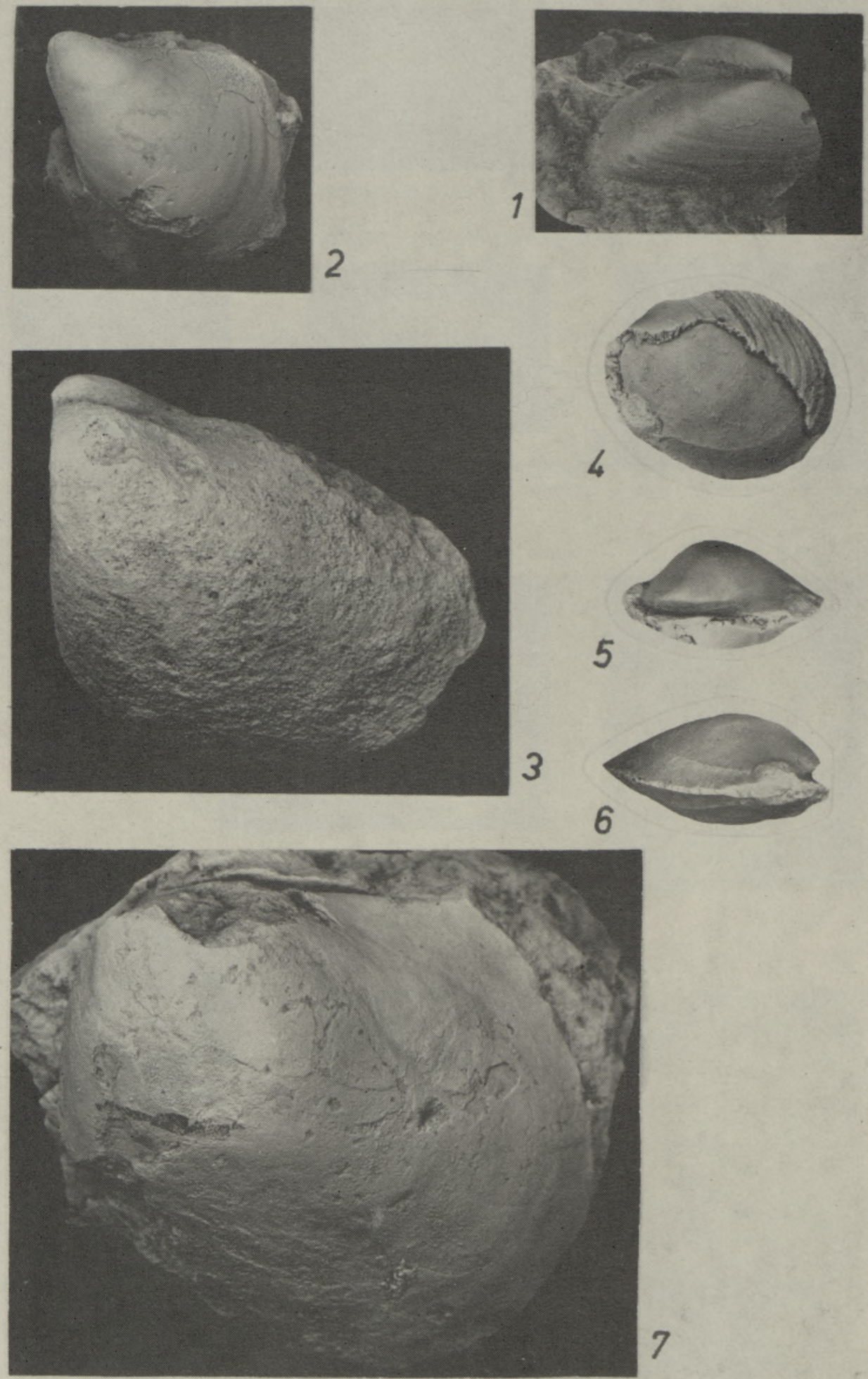
дом (1860, табл. XXXIX, фиг. 26a-в). О-в Хийумаа, Кыргессааре, вормсиский горизонт, кыргессаареская свита (F $\mathrm{F}$ K).

Диагноз. Раковина овальная, вздутая, длиной до 30 мм. Замочный край слабо изогнутый. Коэффициент выпуклости достигает до 0,4. Умбональный гребень округленный, ограниченный позади неглубокой депрессией, развитой примерно от середины высоты створок. Макушки большие, выступающие, спирально закрученные и загнутые вперед. Передний мускульный отпечаток большой, овальный, глубокий; задний более крупный, нечеткий. В каждой створке под макушкой расположен короткий зубовидный выступ, направленный косо назад. Передний мускульный отпечаток крупный, овальный, рельефный, ограниченный с внутренней стороны косым коротким ребром. Задний мускульный отпечаток крупнее переднего, нечеткий. Поверхность ядер покрыта тонкими радиальными струйками.

Геологическое распространение. Эстония. Вормсиский горизонт, кыргессаареская свита $\left(\mathrm{F}_{\mathrm{I}} \mathrm{bK}\right)$ - о-в Хийумаа, Кыргессааре, 1 экз., о-в Вормси, берег у Саксби (северный), 1 экз.

Род Veimarnella Sinicyna, 1983

Veimarnella globosa (Eichwald), 1856

Табл. I, фиг. 9, 10

1856 Pterinea globosa Eichwald, c. 564

1860 Modiolopsis globosa Eichwald, c. 971, табл. XXXVIII, фиг. $4 a-c$

1861 Modiolopsis globosa Eichwald; Эйхвальд, с. 276, табл. XVII, фиг. $4 a-\varepsilon$

1983 Veimarnella globosa (Eichwald); Синицына, с. 29, табл., фиг. $1-5$

Лектотип (выбранный здесь). КИГ ЛГУ, № 1/820, полное ядро, изображенное Э. Эйхвальдом (1860, табл. LI, фиг. $6 a-8)$. Таллин, ласнамягиский горизонт, вяоская свита $\left(\mathrm{C}_{\mathrm{I}} \mathrm{bV}\right)$ или ухакуский горизонт, кыргекаллаская свита $\left(\mathrm{C}_{\mathrm{I}} \mathrm{CK}\right)$. Паратип. КИГ ЛГУ, № $1 / 345$, полное ядро, изображенное И. Н. Синицыной $(1983$, таблица, фиг. 1-5), Ленинградская обл., пос. Веймарн, кукрузеский горизонт, вийвиконнаская свита $\left(\mathrm{C}_{\mathrm{II}} \mathrm{V}\right)$.

Диагноз. Раковины округленно-ромбические, немного скошенные, расширяющиеся назад, очень выпуклые (коэффициент выпуклости до 0,5), длиной до 35 мм. От макушки к вентральному краю проходит гребень, немного сглаживающийся к периферии. На раковинах гребень более угловатый, чем на ядрах, особенно в верхней трети (около $60^{\circ}$ ). Впереди гребня поверхность створок и ядер в верхней половине вогнутая, в нижней - пологовыпуклая. Позади гребня поверхность раковин и ядер пологовыпуклая. На ядрах видна узкая неглубокая депрессия,

\section{ТАБЛИЦА II}

Фиг. 1 - Modiolopsis silurica (Eich.), лектотип № 1/878, ядро правой створки, обломанное спереди, Раквере. Фиг. 2 - Cleionychia devexa (Eich.), лектотип № 1/2195, ядро левой створки, о-в Осмуссаар. Фиг. 3 - Ambonychia incrassata (Eich.), лектотип № 1/813, ядро двустворчатого экземпляра со стороны левой створки, Сааремыйза. Фиг. 4, 5, 6 - Aristerella ? silurica (Eich.), лектотип № $1 / 812$, о-в Осмуссаар, 4 ядро правой створки с остатками раковины, 5- вид со стороны замочного края, 6 - вид со стороны переднего края. Фиг. 7 - Ambonychiopsis excellens (Eich.), голотип № 1/796, ядро левой створки, Сааремыйза. Увеличение всюду $\times 1$. 
проходящая косо назад, к нижней трети заднего края. Макушки очень широкие, округленные, почти не выступающие, немного сдвинутые вперед. Концентрическая скульптура представлена тонкими, низкими, неравномерно расположенными ребрами. Замок состоит из 3-4 кардинальных зубов и одного (?) длинного, тонкого латерального. Передний мускульный отпечаток маленький, округленный, очень рельефный, заостренный; задний - большой, овальный, нечеткий. Поверхность ядер гладкая или с тонкими сглаженными концентрическими морщинами.

Геологическое распространение. Северная Әстония. Ласнамягиский горизонт, вяоская свита $\left(\mathrm{C}_{\mathrm{I}} \mathrm{bV}\right)$ - Вахикюла, 1 экз., Ребала, 3 экз., Лоо, 1 экз., Харку, 1 экз., Таллин, 1 экз. (лектотип). Ухакуский горизонт, кыргекаллаская свита (C I $\mathrm{CK})$ - Эрра, 2 экз., Кыргекаллас, 4 экз., Ухаку, 1 экз., канава у д. Варья, 1 экз., канава у Кохтла-Ярвеского совхоза, 3 экз., Ласнамяги, 5 экз., Палдиски, 2 экз. Кукрузеский горизонт, кохтлаский подгоризонт, вийвиконнаская свита $\left(\mathrm{C}_{\mathrm{II}} \mathrm{V}\right)$ - КохтлаЯрве, 9 экз. (3 из пал. лаб. ЛГУ), Кивиыли (Сала), 1 экз., Эрра, 1 экз., Кюттейыу, 4 экз., карьер Октябрьский, 4 экз., Ууэмыйза, 2 экз., Убья, 2 экз., Ласнамяги, ул. Пунане, 2 экз., канава Пирита-Юлемисте, 2 экз., Харку, 6 экз., Палдиски, 1 экз. Кукрузеский горизонт, хумалаский подгоризонт, вийвиконнаская свита $\left(\mathrm{C}_{\mathrm{II}} \mathrm{V}\right)$ - Хумала, 8 экз., Сыямяги, 2 экз. Ленинградская обл. Ухакуский или кукрузеский горизонт $\left(\mathrm{C}_{\mathrm{I}} \mathrm{c}-\mathrm{C}_{\mathrm{II}}\right)$ - Веймарн, 19 экз., Алексеевка, 2 экз. (все из коллекции пал. лаб. ЛГУ).

Замечание. Вероятно, к этому же виду относятся двустворки, описанные Э. Эйхвальдом как Cypricardia inflata (Eichwald, 1860, с. 1012, табл. LI, фиг. $6 a-8)$. Они характеризуются близкой к $V$. globosa формой створок и значительной выпуклостью (табл. 1, фиг. 8). Однако недостаточно хорошая сохранность не дает возможности безоговорочно отнести их к описываемому виду.

Семейство Ambonychiidae S. A. Miller, 1877

Род Cleionychia Ulrich, 1892

Cleionychia devexa (Eichwald), 1840

Табл. II, фиг. 2

1840 Mytilus devexus Eichwald, c. 127

1856 Pterinea (Mytilus) devexa Eichwald, c. 563

1860 Modiolopsis devexa Eichwald, c. 967, табл. XXXVII, фиг. 30a-6

1861 Modiolopsis devexa Eichwald; Эйхвальд, с. 275, табл. XVI, фиг. $30 a-8$

Лектотип (выбранный здесь). КИГ ЛГУ, № 1/2195, ядро правой створки, изображенное Э. Эйхвальдом (1860, табл. XXXVII, фиг. $30 a-8)$. O-в Осмуссаар, ласнамягиский горизонт, вяоская свита $\left(\mathrm{C}_{\mathrm{I}} \mathrm{bV}\right)$ или ухакуский горизонт, кыргекаллаская свита ( $\left.\mathrm{C}_{\mathrm{I}} \mathrm{K}\right)$.

Диагноз. Раковина косо-овальная, средних размеров, длиной до 40 мм. Вершина верхнего заднего угла четко выражена. Раковина сильно выпуклая (коэффициент выпуклости 0,55). Умбональный гребень округлен и немного изогнут. Макушка конечная, выступающая, повернутая вперед. Ядра покрыты тонкими концентрическими морщинками.

Замечание. Не найдено еще материала, который подтвердил бы данные $Ә$. Әйхвальда о находке $C$. devexa из Сааремыйза, Гостилиц и 
Пулково. Сравнительный материал имеется только с о-ва Осмуссаар. Поскольку из Палдиски и из Таллина также известны обнажения ласнамягиского и ухакуского горизонтов, в дальнейшем там возможны находки этого вида.

Геологическое распространение. Северная Эстония. Ласнамягиский горизонт, вяоская свита $\left(\mathrm{C}_{\mathrm{I}} \mathrm{bV}\right)$ или ухакуский горизонт, кыргекаллаская свита ( $\left.\mathrm{C}_{\mathrm{I}} \mathrm{CK}\right)$ - о-в Осмуссаар, 3 экз. (лектотип и синтип), 3 синтипа из Палдиски или из Таллина (на этикетках указаны оба местонахождения).

\section{Род Ambonychiopsis Isberg, 1934}

Ambonychiopsis excellens (Eichwald), 1856

Табл. II, фиг. 7

1856 Posidonomya excellens Eichwald, c. 558

1860 Posidonomya excellens Eichwald, c. 943, табл. XXXVII, фиг. 15a-в 1861 Posidonomya excellens Eichwald; Эйхвальд, с. 269, табл. XVI, фиг. $15 a-8$

Голотип. КИГ ЛГУ, № 1/796, ядро левой створки, изображенное Э. Эйхвальдом (1860, табл. XXXVII, фиг. 15a-в). Сааремыйза, вормсиский горизонт, кыргессаареская свита ( $\left.\mathrm{F}_{\mathrm{I}} \mathrm{bK}\right)$.

Диагноз. Раковина крупная, округлая, длиной до 80 мм. Передний край округлен и плавно переходит в выпуклый вентральный край, который плавно сливается с задним. Замочный край прямой, образует с задним угол $130^{\circ}$. Раковина умеренно выпуклая (коэффициент выпуклости 0,42$)$. Примакушечная часть сохранилась плохо. Макушки массивные, широкие.

Геологическое распространение. Северная Әстония. Вормсиский горизонт, кыргессаареская свита ( $\left.\mathrm{F}_{\mathrm{I}} \mathrm{bK}\right)$ - Сааремыйза, 1 экз. (голотип).

\section{Род Ambonychia Hall, 1847}

Ambonychia incrassata (Eichwald), 1856

Табл. II, фиг. 3

1840 Mytilus incrassatus Eichwald, c. 126

1856 Pterinea incrassata Eichwald, c. 564

1860 Modiolopsis incrassata Eichwald, c. 966, табл. XXXVIII, фиг. $3 a-в$ 1861 Modiolopsis incrassata Eichwald; Эйхвальд, с. 276, табл. XVII, фиг. $3 a-8$

1975 Ambonychinia incrassata (Eichwald); Синицына, с. 27, табл. II, фиг. 4

Лектотип (выбранный здесь). КИГ ЛГУ, № 1/813, полное ядро, изображенное Э. Эйхвальдом. (1860, табл. XXXVII, фиг. $3 a-8)$. Сааремыйза, вормсиский горизонт, кыргессаареская свита ( $\left.\mathrm{F}_{\mathrm{I}} \mathrm{bK}\right)$.

Диагноз. Раковина большая, длиной до 70 мм, скошенно-угловатая в примакушечной и округленная в нижней части. Передний край скошен назад и плавно сливается с равномерно округленным вентральным краем. Раковина значительно выпуклая (коэффициент выпуклости 0,35 ). Макушки конечные, большие, немного завернутые вперед. Ядра покрыты тонкими концентрическими струйками.

Геологическое распространение. Северная Эстония, Вормсиский гори- 
зонт, кыргессаареская свита ( $\left.\mathrm{F}_{\mathrm{I}} \mathrm{bK}\right)$ - Сааремыйза, 1 экз. (лектотип), p. Ката, 2 экз., о-в Вормси, берег у Саксби (северный), 8 экз., Паопа, 2 экз.

Замечание. Данные Э. Эйхвальда о находках A. incrassata вблизи Таллина не подтверждены, так как экземпляры Эйхвальда оттуда не сохранились, а дополнительный материал отсутствует. На этикетке лектотипа местонахождение - Ликгольм (=Сааремыйза).

Семейство Modiomorphidae Miller, 1877

Род Aristerella Ulrich, 1894

Aristerella ? silurica (Eichwald), 1840

Табл. II, фиг. 4, 5, 6

1840 Pterinea silurica Eichwald, c. 132

1856 Pterinea (Mytilus) silurica Eichwald, c. 563

1860 Pterinea silurica Eichwald, c. 963, табл. XXXVIII, фиг. 5a-в

1861 Pterinea silurica Eichwald; Эйхвальд, с. 274, табл. XVII, фиг. 5a-в

Лектотип (выбранный здесь). КИГ ЛГУ, № 1/812, полное ядро, изображенное Э. Эйхвальдом со стороны правой створки (1860, табл. XXXVIII, фиг. 3). О-в Осмуссаар, ласнамягиский горизонт, вяоская свита $\left(\mathrm{C}_{\mathrm{I}} \mathrm{bV}\right)$ или ухакуский горизонт, кыргекаллаская свита $\left(\mathrm{C}_{\mathrm{I}} \mathrm{cK}\right)$.

Диагноз. Раковина скошенно-овальная, длиной до 33 мм, неравностворчатая, неравносторонняя. Правая створка значительно выпуклая (коэффициент выпуклости 0,33 ), левая - уплощенная. Выпуклость распределяется равномерно. Макушка небольшая, но довольно широкая, расположенная на расстоянии менее $1 / 5$ длины створки от переднего конца. Скульптура концентрическая. Ребра широкие, тупые, неравной ширины, разделенные узкими промежутками. Передний мускульный отпечаток овальный, рельефный, задний не сохранился. Хорошо выражена рельефная простая мантийная линия.

Замечание. Из трех сохранившихся синтипов один - ядро правой створки плохой сохранности. Два других должны быть отнесены к иному роду и виду. По устному сообщению профессора А. Рыымусокса, экземпляры Э. Эйхвальда происходят из ласнамягиского или ухакуского горизонта, т. е. может быть, только из Таллина или с о-ва Осмусcaар, а не с о-ва Хийумаа (по Эйхвальду).

Геологическое распространение. Северная Эстония. Ласнамягиский горизонт, вяоская свита $\left(\mathrm{C}_{\mathrm{I}} \mathrm{bV}\right)$ нли ухакуский горизонт, кыргекаллаская свита ( $\left.\mathrm{C}_{\mathrm{I}} \mathrm{CK}\right)$ - о-в Осмуссаар, 2 экз. (лектотип и синтип).

Род Modiolopsis Hall, 1847

Modiolopsis silurica (Eichwald), 1840

Табл. II, фиг. 1

1840 Cypricardia silurica Eichwald, c. 129

1856 Cypricardia silurica Eichwald, c. 572

1860 Cypricardia silurica Eichwald, c. 1010, табл. XXXIX, фиг. $5 a-8$

1861 Cypricardia silurica Eichwald; Эйхвальд, с. 287, табл. XVIII, фиг. $5 a-8$

Лектотип (выбранный здесь). КИГ ЛГУ, № 1/878, полное ядро, обло- 
манное спереди, изображенное Э. Эйхвальдом (1860, табл. XXXIX, фпг. $5 a-8)$ как целое. Раквере, раквереский горизонт, воореская свита.

Диагноз. Раковина вытянуто-овальная, длиной 40 мм. Вентральный край почти параллелен замочному, задний край округленный. Соединение краев очень плавное. Раковина умеренно выпуклая (коэффициент выпуклости 0,47$)$. От макушки по диагонали раковины протягивается хорошо выраженный гребень. Макушки широкие, сближенные. Скульптура состоит из тонких концентрических ребер.

Замечание. Данные Э. Эйхвальда о находках M. silurica из Қыргесcaаре, Пюхалепа, с о-вов Осмуссаар и Хийумаа и из КаменецкПодольска не подтверждены: эти местонахождения перечислены в монографии, но на этикетках лектотипа и синтипов указано только одно местонахождение - Раквере, а дополнительного материала нет.

Геологическое распространение. Северная Эстония. Раквереский горизонт, воореская свита (EV) - Раквере, 4 экз. (лектотип и 3 синтипа). Набалаский горизонт, сауньяская пачка воореской свиты (FIa V'S). Одулема, 1 экз., Тырма, 1 экз., каменоломня Талдевяля, 1 экз.

Modiolopsis plana (Eichwald), 1840

Табл. I, фиг. 11 xiste

1840 Mytilus planus Eichwald, c. 128

1856 Pterinea (Mytilus) plana Eichwald, c. 563

1860 Avicula plana Eichwald, c. 946, табл. XXXVIII, фиг. 1a-в

1861 Avicula plana Eichwald; Эйхвальд, с. 270, табл. XVII, фиг. 1a-в

Голотип. КИГ ЛГУ, № 1/799, ядро левой створки, изображенное Э. Эйхвальдом (1860, табл. XXXVIII, фиг. $1 a-8)$, окрестности Раквере, раквереский горизонт, или с о-ва Осмуссаар, ласнамягиский или ухакуский горизонт.

Диагноз. Раковина большая, округленно-трапециевидная, длиной до 65 мм, расширяющаяся к заднему концу. Замочный край прямой. Параллельно замочному краю расположен длинный латеральный зуб. Створки слабо выпуклые (коэффициент выпуклости 0,2). Диагональное возвышение очень пологое. Макушки небольшие, слабовыступающие, сильно смещенные вперед. Поверхность ядра покрыта тонкими концентрическими струйками.

Замечание. Не найдено еще дополнительного материала, по которому можно определить стратиграфическое распространение этого вида. Э. Эйхвальд всюду отмечал два местонахождения: Раквере и о-в Осмуссаар. Синтипы относятся к иному роду.

Геологическое распространение. Северная Эстония. Голотип - с о-ва Осмуссаар (ласнамягиский или ухакуский горизонт) или из окрестностей Раквере (оандуский или раквереский горизонт).

\section{ЛИТЕРАТ У РА}

Баулер H. А., Поречкая E. C. Список коллекций монографического отдела музея кафедры исторической геологни. Л., 1959.

Решения межведомственного регионального стратиграфичесқого совещания по разработке унифицированных стратиграфнческих схем Прибалтики, 1976 г. Л., 1978. 
Рыымусокс A. K. Стратиграфия вируской и харьюской сернй (ордовик) Северной Эстонни, I. Таллин, 1970.

Синицына Н. Н. Двустворчатые моллюски молодовского и низов китайского горизонтов Подолин. - Вопр. палеонтол., 1975, 7, 25-40.

Синицына Н. Н. Новый род двустворчатых моллюсков из среднего ордовика СевероЗапада Русской платформы. - В кн.: Палеонтологический сборник. Львов, $1983,20,29-31$

Эйхвальд Э. Палеонтология Россин. Древний период. СПб., 1861, ч. II, 265-299.

Eichwald, E. Ober das silurische Schichtensystem in Estland. - St. Petersburg, 1840.

Eichwald, E. Beitrag zur geographischen Verbreitung der fossilen Thiere Russlands. Alte Periode. - Bull. Soc. Nat. Moscow., 1856, 39, 555-579.

Eichwald, E. Lethaea Rossica ou Paleontologie de la Russie. Stuttgart, 1860. 1, Part 2, 930-1041.

McAlester, A. L. Type species of Paleozoic nuculoid bivalve genera, - Geol. Soc. America Mem., 1968, 105, $1 \multimap 143$.

McAlester, A. L. Superfamily Ctenodontacea in Moore R. C. (ed.). Treatise on Invertebrate Paleontology, Part N (Mollusca 6), 2. - Kans. Geol. Soc. America and Univ. Kansas Press, 1969, 227-229.

Pojeta, J. Jr. The origin and early taxonomic diversification of pelecypods. - Phil. Trans. Roy. Soc. B., 284, 1978, 225-246.

Тартуский государственный университет

Поступнла в редакцию 1/VI 1983

Ленинградский государственный университет

Mare ISAKAR, Irina SINITSONA

\section{E. EICHWALDI KIRJELDATUD ORDOVIITSIUMI KARPIDEST}

Leningradi Riikliku Ulikooli ajaloolise geoloogia kateedri muuseumis säilitatakse E. Eichwaldi poolt Eestist ja Leningradi oblastist kogutud ordoviitsiumi karpe. Tegemist on erineva säilimisastmega sisevalatistega. Artiklis on täpsustatud 11 liigi perekondlikku kuuluvust ning stratigraafilist levikut.

Mare ISAKAR, Irina SINITSYNA

\section{REDESCRIPTION OF E. EICHWALD'S ORDOVICIAN BIVALVE SPECIES}

E. Eichwald was the first to describe (Eichwald, 1840; Eichwald, 1856; Eichwald, 1860; Эйхвальд, 1861) the bivalve fauna of the Ordovician rocks of Estonia. His specimens are housed now in the Museum of the Chair of Historical Geology of Leningrad State University. E. Eichwald described in varying detail the species mentioned in this paper. The localities of a number of specimens in E. Eichwald's old collections are uncertain, or the labels are lost.

The present article describes in brief the following Middle and Upper Ordovician bivalve species: Tancrediopsis macromya (Eich.), Dystactella ? aedilis (Eich.), Cyrtodontula ? esthona (Eich.), Plethocardia obtusa (Eich.), Veimarnella globosa (Eich.), Ambonychia incrassata (Eich.), Cleionychia devexa (Eich.), Ambonychiopsis excellens (Eich.), Aristerella ? silurica (Eich.), Modiolopsis plana (Eich.), Modiolopsis silurica (Eich.). 